\title{
Polycystic ovary syndrome and mental disorders - discussion on the recommendations of the European Society of Human Reproduction and Embryology (ESHRE)
}

Zespół policystycznych jajników a zaburzenia psychiczne - omówienie rekomendacji European Society of Human Reproduction and Embryology (ESHRE)

Magdalena Derewianka-Polak ${ }^{1}$ ABEF https://orcid.org/0000-0002-4283-9301,

Grzegorz Polak² ABEF https://orcid.org/0000-0002-4436-2893, Joanna Tkaczuk-Włach³ EF https:// orcid.org/0000-0002-4800-3740, Aneta Gerhant ${ }^{1}$ EF https://orcid.org/0000-0002-4196-5437, Marcin Olajossy ${ }^{1}$ E https://orcid.org/0000-0002-1001-3185,

${ }^{1}$ II Department of Psychiatry and Psychiatic Rehabilitation, Medical University of Lublin, Poland ${ }^{2}$ I Chair and Department of Oncological Gynaecology and Gynaecology, Medical University of Lublin, Poland ${ }^{3}$ Chair and Department of Gynaecology and Gynaecological Endocrinology, Medical University of Lublin, Poland

\begin{abstract}
Introduction: Polycystic ovary syndrome (PCOS) is the most common endocrinopathy in women at the reproductive age. In 2018, the European Society of Human Reproduction and Embryology (ESHRE) developed and published new accurate recommendations for the diagnosis and management of women with PCOS. In this work, a separate chapter is devoted to the quality of life and mental disorders in patients with polycystic ovary syndrome.

Material and Methods: This article provides an overview of the literature regarding mental disorders associated with PCOS with the focus on the ESHRE recommendations.

Conclusion: The medical staff and patients should be aware of the negative impact of polycystic ovary syndrome on the quality of life, coexistence of depression, anxiety, psychosexual and eating disorders.
\end{abstract}

Keywords: polycystic ovary syndrome, psychiatric disorders, recommendations.

\section{Streszczenie}

Wstęp: Zespół policystycznych jajników (PCOS) jest najczęstszą endokrynopatią występującą u kobiet w wieku rozrodczym. W 2018 roku Europejskie Towarzystwo Rozrodu Człowieka i Embriologii (ESHRE) opracowało wytyczne dotyczące diagnostyki i leczenia kobiet z PCOS. W rekomendacjach tych osobny rozdział poświęcono zaburzeniom psychicznym towarzyszącym zespołowi policystycznych jajników.

Materiał i Metodyka: W pracy zawarto przegląd literatury dotyczącej zaburzeń psychicznych u kobiet z PCOS, ze szczególnym uwzględnieniem rekomendacji ESHRE.

Wnioski: Zarówno personel medyczny, jak i pacjentki, powinni być świadomi negatywnego wpływu zespołu policystycznych jajników na jakość życia oraz na współistnienie depresji, lęku, zaburzeń psychoseksualnych i odżywiania.

Słowa kluczowe: zespół policystycznych jajników, zaburzenia psychiczne, rekomendacje.

Polycystic ovary syndrome (PCOS - Polycystic Ovary Syndrome) is the most common endocrinopathy in women at the reproductive age. Depending on the diagnostic criteria, it occurs in $10 \%-20 \%$ of women. For many years, PCOS has been recognized on the basis of various symptoms of this disease. In 2003, during the joint meeting of ESHRE (European Society of Human Reproduction and Embryology) and ASRM (American Society for Reproductive Medicine) in Rotterdam, the current criteria for the diagnosis of polycystic ovary syndrome were 
adopted in order to harmonize the diagnostic process [1]. These include hyperandrogenemia or hyperandrogenism, characteristic ultrasound of the ovaries and menstrual disorders such as rare menstruation or the absence of menstrual bleeding. To diagnose PCOS, two of the three symptoms described need to occur (Rotterdam criteria). At the same time, it is recommended to exclude other causes of menstrual disorders such as thyroid disease or hyperprolactinemia and diseases associated with the increased production of androgens, including Cushing's syndrome, androgen-producing tumors or congenital adrenal hyperplasia.

Due to the heterogeneous clinical picture of polycystic ovary syndrome during the National Institutes of Health meeting in 2012 [2], four phenotypes of this disease were identified:

1. excess of androgens + menstrual disorders + polycystic ovary picture (phenotype A)

2. excess of androgens + menstrual disorders (phenotype B)

3. excess of androgens + polycystic ovary picture (phenotype C)

4. menstrual disorders + polycystic ovary picture (phenotype D)

Polycystic ovary syndrome exerts a huge impact on women's health due to the accompanying problems such as infertility, acne, hirsutism, obesity, metabolic syndrome, insulin resistance, diabetes, hypertension, dyslipidemia and endometrial cancer [3]. Therefore, PCOS has a negative impact on the quality of life, often leading to depression and anxiety disorders.

Due to the constant progress of medical knowledge, in 2018 the European Society of Human Reproduction and Embryology developed and published new accurate recommendations for the diagnostic process and management of women with PCOS [4]. In this work, a separate chapter is devoted to the quality of life and mental disorders in patients with polycystic ovary syndrome. Its aim is to make the medical staff and patients aware of the negative impact of the disease on the quality of life, coexistence of depression, anxiety, psychosexual and eating disorders.

Having analyzed the five papers that used the Short Form 36 (SF-36) and three studies based on the World Health Organization (WHO) form, it was found that healthrelated quality of life is worse in women with PCOS than in healthy women. Yet, it was emphasized that the analyzed research was not of high quality. The result, however, cannot be surprising. The symptoms co-occurring in women with polycystic ovary syndrome such as infertility, menstrual disorders, hirsutism and acne disturb selfperception, reinforce low self-esteem, depressive symptoms and anxiety disorders. In addition, the quality of life is often reduced by a delayed diagnosis of the disease and insufficient level of education and information provided to patients. Therefore, ESHRE recommendations suggest estimating the quality of life in women with polycystic ovary syndrome. It was recommended to use the PCOSQ and MPCOSQ scales in order to assess the emotional state, hirsutism, acne, infertility and menstrual disorders [4].

The analysis of the available literature has shown that women with polycystic ovary syndrome have an increased risk of depression of varying severity. Statistically significantly more often, they experience fatigue, sleep disturbances and diminished interest compared to women without PCOS. Interestingly, the presence of depressive symptoms is not related to obesity, which accompanies some patients with PCOS. Medium and high degree of anxiety disorders are also significantly more frequent in the group of patients with polycystic ovary syndrome, regardless of the studied ethnic group. Some studies have even shown that this risk may be up to seven times higher than in women without PCOS. The causes of depression and anxiety disorders in patients with polycystic ovary syndrome have not been precisely defined. The presence of acne, hirsutism and obesity is associated with mood disorders and feelings of regret. Depression and anxiety may also result from the chronic and frustrating nature of the condition that affects the quality of life in a negative way. It seems that the incidence of anxiety disorders and depression in women with polycystic ovarian syndrome is higher in adolescents than in adult patients compared to those without disease.

Therefore, ESHRE recommends routine screening for depression and anxiety disorders in every woman diagnosed with PCOS. In the case of their occurrence, the patient should be given a recommendation to a specialist. The time after which the effects of the therapy should be checked has not been clearly defined, leaving this decision to the treating physician.

The first stage of screening may involve posing the question:

In the last 2 weeks:

- did you feel depressed or hopeless?

- did you experience diminished interest or lack of pleasure in everyday life?

- were you nervous or anxious?

-were you not able to stop worrying or controlling your worry?

If any of the answers to these questions is positive, it is recommended to conduct further screening including the assessment of risk factors for depression and anxiety disorders in line with national recommendations. The PHQ (Patient Health Questionnaire) and GAD7 (Generalized Anxiety Disorder Scale - 7) forms can be helpful for this 
purpose. Further proceedings include referring the patient to a specialist [4].

It is recommended to be cautious when qualifying patients for treatment with antidepressants and anxiolytics. When using pharmacotherapy in patients with PCOS, it is recommended to avoid drugs that may cause weight gain. It is also necessary to treat obesity, infertility and hirsutism co-accompanying PCOS. It should be remembered that hormonal contraception used in PCOS therapy may exacerbate symptoms of depression and anxiety disorders and negatively affect other aspects of emotional well-being.

The prevalence of psychosexual disorders in women with PCOS is estimated in the range from $13.3 \%$ to as much as $62.5 \%$. Due to such a large discrepancy in literature data, it is difficult to unequivocally assess whether in this group of women these disorders occur more often in comparison to the general population. It seems, however, that depression, low self-esteem and disturbed body image increase the risk of psychosexual disorders in this group of women. It has been shown that hormonal contraception used to regulate the sexual cycle, as well as ovulatory drugs can cause psychosexual disorders in the general female population. The current state of knowledge, however, does not allow to draw similar conclusions in the group of patients with PCOS. Infertility and menstrual disorders result in the loss of femininity attributes in the eyes of the patient and may lead to a feeling of reduced attractiveness, which affects their sexuality. In addition, obesity, hirsutism and the presence of acne, according to the surveyed women, negatively affect sexual attraction. It should be emphasized, however, that in some of the papers there was a similar incidence of sexual dysfunctions in women with and without PCOS.

Despite the ambiguous data on the higher incidence of psychosexual disorders in patients with polycystic ovary syndrome, if there is a suspicion that they might occur, ESHRE recommends that the diagnosis should be implemented in sexually active women. The Female Sexual Function scale [4] may be helpful in their assessment.

There is not enough evidence in the available literature to unambiguously state that women with polycystic ovary syndrome have a distorted body image. Although the MBSQR (Multidimensional Body-SelfResponse Questionnaire) questionnaire indicated such conclusion, yet the results of other studies did not show such dependencies.

It seems, however, that the PCOS with the accompanying hirsutism and obesity negatively affect women's self-perception. An abnormal body image may also be affected by infertility and co-occurring depression.

Therefore, ESHRE experts believe that medical personnel as well as patients with PCOS should be aware that the symptoms of the disease may negatively affect the body image. For the purpose of its evaluation, a two-stage screening can be used.

The recommended preliminary questions include:

1. Do you worry about your appearance and would you like to think less about it?

2. Do you spend over an hour a day on a normal day worrying about your appearance?

3. Do you have any particular concerns about your appearance?

4. Does it affect your life?

5. Is it difficult to work or stay with friends and family?

If the problem is confirmed, it is recommended to:

1. identify the cause of the disturbed perception of one's own body and implement appropriate therapy;

2. evaluate the level of depression and anxiety disorders;

3. identify the degree of distortion of the body image and the occurrence of eating disorders.

Body assessment scales may be helpful in screening. Detection of a negative body image will allow the implementation of appropriate psychological help in order to restore proper self-esteem and self-acceptance, as well as direct the treatment towards the causes of this condition such as hirsutism, acne or overweight.

Polycystic ovary syndrome is characterized by the presence of risk factors characteristic of eating disorders / disordered eating such as: obesity, depression, anxiety, low self-esteem and disturbed body image [5, 6]. Therefore, it seems that eating disorders are more common in this group of patients. Some of them do not meet all diagnostic criteria of eating disorders, however, attention should be paid to getting drunk frequently, using drastic diets or starving.

At present, we do not have enough clinical data to be certain that eating disorders / disordered eating are more common in patients with PCOS. However, the available test results suggest such a relation. It was found that eating disorders may occur in up to $21 \%$ of PCOS women compared to $4 \%$ of the general population, although no such differences were found in bulimia (12\% vs. $4 \%$ ). The analysis of the register of 24385 women with PCOS showed a higher incidence of bulimia but not anorexia nervosa [8]. The results of other studies bring divergent results $[7,8]$ but suggest an increased incidence of eating disorders / disordered eating in the case of polycystic ovary syndrome.

Significantly higher incidence of eating disorders / disordered eating in women with PCOS together with the negative psychosocial consequences of these pathologies indicate the need to disseminate knowledge on this subject. The recommendations of The National Institute 
for Health and Care Excellence (NICE) regarding eating disorders suggest the medical staff to be aware of the necessity to diagnose eating disorders in the case of PCOSspecific symptoms. Awareness of this problem will allow for faster diagnosis and treatment of eating disorders, which may translate into improving the quality of patients' lives as well as a decrease in the risk of negative health consequences [9].

Many women with eating disorders are undiagnosed and unaware of their problem. At the moment, there are no standardized, widespread research tools for studying eating disorders, which, combined with their complex nature, makes screening and the diagnostic process difficult.

The presence of risk factors for eating disorders / disordered eating in women with PCOS is, according to ESHRE experts, a sufficient condition to assess their occurrence. The ESHRE recommendations emphasize that the available tools for assessing eating disorders are of poor quality and that none of them used alone is able to identify the problem. Therefore, a clinical interview is extremely important for diagnosis. The SCOFF form (Sick, Control, One stone, Fat, Food) is the most commonly used screening tool in adults. However, when used alone, it is characterized by the risk of false positive results, exposing the patient to unnecessary therapy.

According to ESHRE recommendations, apart from a clinical interview, screening of PCOS patients for disordered eating / eating disorders may include a SCOFF form or questions:

1. Does your body weight affect the way you think about yourself?

2. Are you satisfied with your eating habits?

If the SCOFF questionnaire or the answers to the above questions are positive, further recommendations include the assessment of the risk factors and symptoms, taking into account the patient's age and national standards in this area, as well as referring the patient to a specialist [4].

In conclusion, it should be noticed that the recommendations of the highly opinion-forming European Society of Human Reproduction and Embryology put great emphasis on the diagnosis of mental disorders. Polycystic ovary syndrome is the most common endocrinopathy of women at the reproductive age. Therefore, the increased awareness of medical staff and women with PCOS regarding the possible psychological consequences of the disease will allow for a quicker diagnosis and referring this group of patients to psychiatrists. At the same time, it seems appropriate that knowledge about the coexistence of PCOS and psychiatric disorders should be disseminated among psychiatrists to spread it in their environment. Polycystic ovary syndrome is a multidisciplinary disease.
Due to numerous accompanying health complications, patients with PCOS may report their problems not only to the gynecologist but also to the specialists of family medicine, internal diseases, endocrinology, diabetology, dermatology or oncology. Their awareness of the need to pay attention to possible psychiatric problems associated with polycystic ovary syndrome will allow for faster intervention in this group of women provided by psychiatrists.

\section{Conflict of interest}

The authors have declared no conflict of interest.

\section{References}

1. Rotterdam ESHRE / ASRM-Sponsored PCOS Consensus Workshop Group. Revised 2003 consensus on diagnostic criteria and long-term health risk related to polycystic ovary syndrome. Fertil. Steril. 2004; 81 (1): 19-25.

2. National Institutes of Health Evidence-based methodology workshop on polycystic ovary syndrome, December 3-5, 2012. Executive summary. https://prevention.nih.gov/docs/ programs/pcos/FinalReport.pdf.

3. Fauser BC, Tarlatzis BC, Rebar RW, Legro RS, Balen AH, Lobo R, et al. Consensus on women's health aspects of polycystic ovary syndrome (PCOS): the Amsterdam ESHRE / ASRM-Sponsored 3rd PCOS Consensus Workshop Group. Fertil. Steril. 2012; 97 (1): 28-38.e25

4. Teede HJ, Misso ML, Costello MF, Dokras A, Laven J, Moran L, et al. International PCOS Network. Recommendations from the international evidence-based guideline for the assessment and management of polycystic ovary syndrome. Hum. Reprod. 2018; 33 (9): 1602-1618.

5. Hollinrake, E., Abreu A, Maifeld M, Van Voorhis BJ, Dokras A. Increased risk of depressive disorders in women with polycystic ovary syndrome. Fertil Steril. 2007: 87 (6): 1369-76.

6. Karacan, E., Caglar GS, Gürsoy AY, Yilmaz MB. Body Satisfaction and Eating Attitudes among Girls and Young Women with and without Polycystic Ovary Syndrome. Journal of Pediatric and Adolescent Gynecology. 2014. 27 (2): 72-77.

7. Siu, AL and USPSTF on behalf of the United States. Annals of Internal Medicine. 2016. 164 (5): 360-366.

8. Larsson, I., Hulthén L, Landén M, Palsson E, Janson P, StenerVictorin E. Dietary intake, resting energy expenditure, and eating behavior in women with and without polycystic ovary syndrome. Clinical Nutrition. 2016; 35 (1): 213-218.

9. National Guideline Alliance, NICE Guideline. Eating Disorders: recognition and treatment. Methods, evidence and recommendations. Draft. 2016, National Institute for Health and Care Excellence: London.

\section{Corresponding author}

Grzegorz Polak,

I Chair and Department of Oncological Gynaecology and Gynaecology, Medical University of Lublin ul. Staszica 16, 20-081 Lublin, Poland

Otrzymano: 01.11.2019

Zrecenzowano: 09.02.2020

Przyjęto do druku: 17.02.2020 